\title{
The Evaluation of E-learning Programs in Higher Education Using the CIPP Model (The Empiric Study in Two Institutions of Sasmita Jaya Foundation)
}

\author{
Ubaid Al Faruq ${ }^{1}$, Saiful Anwar ${ }^{2}$, Lodya Sesriyani ${ }^{3}$ \\ Pamulang University \\ ubaidalfaruq@unpam.ac.id ${ }^{1}$,dosen00902@unpam.ac.id², dosen01852@unpam.ac.id ${ }^{3}$

\begin{abstract}
Two institutions of the Sasmita Jaya Foundation have been implementing blended Learning starting in 2016. Therefore, an evaluation of the program is needed. The type of eLearning program evaluation that used in this research is the CIPP model. The results of this evaluation found that (1) the main need is the program implementation, the first providing all meeting using full eLearning, the second is as a supplement given to students; (2) In the form of learning design, this program is not entirely complete and it has not been compiled in digital form; (3) eLearning program process shows that learning activities already refer to learning outcomes; (4) eLearning program still encourages improvement in cognitive aspects only. The authors recommend that the eLearning program can be continued, however the institution should paying attention to the development and quality of the learning object used, the material, interaction, and the learning management system used.
\end{abstract}

Keywords: CIPP, e- Learning, Higher Education.

\section{Introduction}

E-learning is learning with communication and information technology assist, especially the web and internet (Jacobson, Chapman, Ye, \& Van Os, 2017; Sun, Tsai, Finger, Chen, \& Yeh, 2008). Nowadays, e-learning is increasingly popular (Allen \& Seaman, 2010) and it is considered analternative in face-to-face lectures (Crawford-Ferre, Heather GlynnWiest, Lynda R., 2012; Wuebker, 2013). By using e-learning, learning can be carried out anywhere and anytime (Jacobson et al., 2017), without having a classroom to carry out learning.

E-learning is often used interchangeably with e-learning, distance learning, and blended learning. These four terms have different meanings and always associated with face-to-face learning. Face-to-face learning is defined as a traditional mode of communication between students and lecturers which usually occurs in the classroom and it is formal (Baragash \& AlSamarraie, 2018). According to Baragash and Al-Samarraie (Baragash \& Al-Samarraie, 2018), in face-to-face learning, the classroom becomes a place of interaction between students and lecturers and among students, understand and discuss learning tasks, collaborate with peers, and study independently. In classroom learning, interactions occur synchronously, using direct feedback and interactions occur synchronously (at the same place and time).

According to Clark \& Mayer, e-learning as learning that delivered on digital devices such as computers or mobile devices that are intended to support learning (Ruth C. Clark \& Mayer, 2011). Furthermore, they was stated that e-learning as the use of media as a tool to convey content and delivery methods. Nichols (Nichols, 2003) defines e-learning as learning by using the web or something that has abilities similar to the web for learning purposes. Different from 
Nichols, according to Clark (R. Colvin Clark, 2002), media that can be used for learning purposes not just the web, learning can be delivered via CDROM, internet or intranet, and it also through audio and videotape, satellite broadcasting, and interactive television.

Designing programs and learning that encourage engagement is an important thing that has an impact on student persistence in completing lectures. Student persistence in learning is a measure of the quality of teaching (Pascarella, Seifert, \& Whitt, 2008). Given engagement as behavior that is influenced by learning and program interventions (George D. Kuh et al., 2008; Lee, 2014), therefore lecturers need to realize that e-learning requires expertise in designing learning that it is able to encourage engagement. Helping students to engage in learning is an important issue in learning technology research (Henrie, Halverson, \& Graham, 2015; Wang, 2017).

Some causes of the increased the use of e-learning in educational institutions include the availability of various Learning Management System (LMS) software, which is software used to manage, store and deliver education. LMS is a system that has functions ranging from managing educational records to the distribution of material via the Internet by offering features for online collaboration (Sallum, 2008). Salum (Sallum, 2008) describes LMS as an application that allows delivery and administration of content and resources to all students. LMS is a system of applications and software features that make learning content easily accessible and managed. In addition, LMS helps instructors to provide learning materials to students and manage student registration.

Although learning is carried out using LMS, learning certainly have to encourage engagement (behavior, social, and cognitive) or is called active learning. Active learning is basic and underpins all aspects of student involvement. Active learning is learning that involves students in every class activity, involving students to do and think about things they do (Bonwell \& Eison, James, 1991). In active learning, students are actively involved in examining, questioning, and connecting new ideas with old ones, so as to achieve deep learning types (Barkley, 2010). In active learning, students participate in reflecting and monitoring the process and results of learning.

However, in implementation, e-learning in higher education has raised concerns about the quality (Chen, Lambert, \& Guidry, 2010) and the effectiveness of learning (Markova, Glazkova, $\&$ Zaborova, 2017). Meanwhile, the literature shows that participation in e-learning is a vital factor. Participation is a form of involvement, and it is a measure of quality (Shukor, Tasir, Van der Meijden, \& Harun, 2014) as well as effectiveness (Mashaw, 2012). Involvement is considered a prerequisite in learning success (Dixson, 2015; Fredricks, Blumenfeld, \& Paris, 2004). Academic failure is the result of a lack of involvement in the long term (Randolph, Fraser, \& Orthner, 2004), so it certainly encourages involvement as an alternative to help prevent the adverse effects of academic failure. Some of the disadvantages of e-learning that are considered to have an impact on academic failure are mentioned by Suatarma (2014), namely (a) there is a tendency to ignore social aspects in the process; (b) learning that is considered likely leading to training than the concept of education; (c) uneven internet facilities in various regions reduce the level of learning motivation; (d) lack of face-to-face interaction between educators and students.

Seeing the disadvantages and advantages of implementing e-learning in Higher Education, the author tries to evaluate 2 Universities in South Tangerang City under Sasmita Jaya Foundation, and it has implemented an elearning program since 2016. South Tangerang City is now a city Reliable investment in education, as a new city, South Tangerang can be said to have a fairly rapid development in the field of education and it will be a strong candidate for KEK (Special Economic Zone) in the education sector, based on this feasible and deserving of these 
2 universities for program evaluation.

Program evaluation according to some experts such as Jones (1994) is an activity designed to weigh the benefits of the program. Meanwhile, according to Jauch and Glueck (1999) stated that evaluation is the stage of the strategic management process in which management tries to ensure that what they choose is carried out appropriately and achieves goals. The definition of evaluation proposed by Edwind Wandt and Gerald W. Brown (1957) is an action or something that determines the value of something. Another definition by (Worthen and Sanders: 1987) which says that evaluation is the activity of looking for something valuable about something; in looking for something, it also includes seeking benefits in assessing the existence of a program, production, procedures, and alternative strategies proposed to achieve predetermined goals.

This article uses an evaluation of the CIPP model program developed by Stufflebeam known as the CIPP Evaluation Model. CIPP stands for Context, Input, Process and Product. In the book Applied Research by Endang Mulyatiningsih (2011), she suggests that the CIPP evaluation is known as formative evaluation with the aim of making decisions and improving programs. The formulation of the problem that is answered in this article is how are the results of the evaluation using the CIPP model for e-learning programs in both universities? Which aims to determine the results of the evaluation using the CIPP model e-learning program and provide recommendations for the sustainability of the program.

In evaluating using the CIPP program, the author explores the evaluation context in terms of needs analysis and basic references. The input components in the e-learning program evaluation are (1) Learning design; (2) Procedure; (3) Institutions; (4) human resources; (5) Facilities and infrastructure; (6) Learning resources. In the process component there are 7 aspects that are evaluated, including (1) Learning activities; (2) Learning strategies; (3) Interaction; (4) The use of media and learning technology; (5) feedback system; (6) Evaluation of student progress; and (7) learning assistance services. Finally, the product components of the e-learning program include the outputs and outcomes product.

\section{Methodology}

The universities used as locations, namely (1) Pamulang University and (2) STMIK ERESHA, both of which are in South Tangerang City with the methods used in data collection, namely: (a) Observation method: this method is carried out using instruments, which in the form of an observation sheet and questionnaire / questionnaire in the implementation of e-learning program evaluation using the CIPP method; (b) Interview method: before conducting interviews to research subjects, the researcher prepares a framework of questions in conducting an evaluation of Natural Sciences learning using the CIPP method. This method is used to clarify the results of observations so that problems can be seen in depth and in detail. The sources of information used as sources are shown in Table 1 about the research instrument grids; (c) Discussion and documentation methods: this method is used to find data about matters or variables in the form of notes, books, newspapers, magazines, agendas, and so on.

Table 1. Instrument Grid

\begin{tabular}{llllll}
\hline No & Stage & Aspect & Success Criteria & Informant & Kind of Instrument \\
\hline 1 & Contexts & a. Need & Appropriate to Permenristekdikti & Rector, Vice Rector 1, & Interview \& \\
& Analysis & $\begin{array}{l}\text { No. 44 Tahun 2015 About } \\
\text { the National Standards of Higher }\end{array}$ & $\begin{array}{l}\text { Chair of } \\
\text { the Institute, }\end{array}$ & Documentation
\end{tabular}




\begin{tabular}{|c|c|c|c|c|c|}
\hline No & Stage & Aspect & Success Criteria & Informant & Kind of Instrument \\
\hline & & & Education; & Permenristekdiktii & \\
\hline & & b. Reference & $\begin{array}{l}\text { Appropriate to Permendikbud No. } \\
109 \text { Tahun } 2013 \text { about the } \\
\text { Implementation of Distance } \\
\text { Education in Higher Education; }\end{array}$ & $\begin{array}{l}\text { Rector, Vice Rector 1, } \\
\text { Chair of the Institute, } \\
\text { Permendikbud }\end{array}$ & $\begin{array}{l}\text { Interview \& } \\
\text { Documentation }\end{array}$ \\
\hline \multirow[t]{6}{*}{2} & Input & $\begin{array}{l}\text { a. Learning } \\
\text { Plan }\end{array}$ & $\begin{array}{l}\text { RPS and SAP are available; } \\
\text { Course identity is clear; } \\
\text { The Leaning goal is clear; } \\
\text { Availability of material maps and } \\
\text { competencies in visual form; } \\
\text { There are formulation of } \\
\text { competency standards and } \\
\text { indicators of competency } \\
\text { achievement; } \\
\text { Shows systematic material } \\
\text { sequence; }\end{array}$ & $\begin{array}{l}\text { Lecturer, RPS \& SAP; } \\
\text { RPS \& SAP; } \\
\text { RPS; } \\
\text { Lecturers \& curriculum } \\
\text { documents; } \\
\text { Lecturers \& curriculum } \\
\text { documents; } \\
\text { Lecturer \& RPS; }\end{array}$ & $\begin{array}{l}\text { Interview \& } \\
\text { Documentation } \\
\text { Interview } \\
\text { Interview } \\
\text { Interview \& } \\
\text { Documentation } \\
\text { Interview \& } \\
\text { Documentation } \\
\text { Interview \& } \\
\text { Documentation }\end{array}$ \\
\hline & & b. Procedure & $\begin{array}{l}\text { The availability of a complete e- } \\
\text { learning procedure document. }\end{array}$ & $\begin{array}{l}\text { Vice Rector 1 / Chair of } \\
\text { the Institute/ head of } \\
\text { study program }\end{array}$ & $\begin{array}{l}\text { Interview \& } \\
\text { Documentation }\end{array}$ \\
\hline & & c. Institution & Has a special institution & Vice Rector 1 & $\begin{array}{l}\text { Interview \& } \\
\text { Observasion }\end{array}$ \\
\hline & & $\begin{array}{l}\text { d. Human } \\
\text { Resources }\end{array}$ & $\begin{array}{l}\text { Completeness of human resources, } \\
\text { ranging from operators, } \\
\text { technicians, programmers, and } \\
\text { management leaders of the } \\
\text { Institute; }\end{array}$ & $\begin{array}{l}\text { Vice Rector } 2 \text { and head of } \\
\text { study program }\end{array}$ & $\begin{array}{l}\text { f Interview, Observation } \\
\text { \& Documentation }\end{array}$ \\
\hline & & $\begin{array}{l}\text { e. Facilities } \\
\text { and } \\
\text { Insfrastructu } \\
\text { re }\end{array}$ & $\begin{array}{l}\text { A qualified LMS; } \\
\text { Adequate server and network; } \\
\text { Computer availability; } \\
\text { Mobile device; } \\
\text { Availability of teleconverence } \\
\text { space. }\end{array}$ & $\begin{array}{l}\text { LMS } \\
\text { Head of IT \& Server Lab. } \\
\text { Computer } \\
\text { Students Teleconverence } \\
\text { room }\end{array}$ & $\begin{array}{l}\text { Observation } \\
\text { Interview, Observation } \\
\text { \& Documentation } \\
\text { Interview, Observation } \\
\text { \& Documentation }\end{array}$ \\
\hline & & $\begin{array}{l}\text { f. Learning } \\
\text { sources }\end{array}$ & $\begin{array}{l}\text { Diversity of learning resources; } \\
\text { Rich with external links; } \\
\text { Appropriate reference to the } \\
\text { material; }\end{array}$ & $\begin{array}{l}\text { Lecturer and Learning } \\
\text { Resources } \\
\text { Lecturer and Link } \\
\text { Lecturer and Reference }\end{array}$ & $\begin{array}{l}\text { Observation \& } \\
\text { Documentation } \\
\text { Observation \& } \\
\text { Documentation } \\
\text { Interview \& } \\
\text { Documentation }\end{array}$ \\
\hline \multirow[t]{3}{*}{3} & Process & $\begin{array}{l}\text { Learning } \\
\text { Activities }\end{array}$ & \multicolumn{2}{|c|}{$\begin{array}{l}\text { The learning process is designed to Lecturer } \\
\text { refer to learning achievements in a } \\
\text { coherent and comprehensive } \\
\text { manner; }\end{array}$} & $\begin{array}{l}\text { Interview \& } \\
\text { Observation } \\
\text { Documentation }\end{array}$ \\
\hline & & & $\begin{array}{l}\text { Varied presentations; } \\
\text { Presentation allows students to } \\
\text { learn interactively independently. }\end{array}$ & $\begin{array}{l}\text { Lecturer \& LMS Lecturer } \\
\& \text { Student }\end{array}$ & $\begin{array}{l}\text { Interview \& } \\
\text { Observation Interview } \\
\text { \& Observation }\end{array}$ \\
\hline & & $\begin{array}{l}\text { Learning } \\
\text { Strategy }\end{array}$ & $\begin{array}{l}\text { Implemented in groups, } \\
\text { independently, or guided; } \\
\text { Availability of guiding questions, } \\
\text { initiations, case studies; } \\
\text { Systematic presentation of learning } \\
\text { objects; } \\
\text { Allows students to practice and } \\
\text { master skills; }\end{array}$ & $\begin{array}{l}\text { Lecturer \& Student } \\
\text { Lecturer } \\
\text { g }\end{array}$ & $\begin{array}{l}\text { Interview \& } \\
\text { Observation }\end{array}$ \\
\hline
\end{tabular}




\begin{tabular}{|c|c|c|c|c|c|}
\hline No & Stage & \multirow[t]{2}{*}{ Aspect } & \multirow[t]{2}{*}{ Success Criteria } & \multirow{2}{*}{$\begin{array}{l}\text { Informant } \\
\text { Lecturer Lecturer }\end{array}$} & \multirow[b]{2}{*}{$\begin{array}{l}\text { Kind of Instrument } \\
\\
\text { Interview \& } \\
\text { Observation } \\
\text { Interview \& } \\
\text { Observation \& } \\
\text { Documentation }\end{array}$} \\
\hline & & & & & \\
\hline & & Interaction & $\begin{array}{l}\text { Provided the opportunity to } \\
\text { interact optimally. }\end{array}$ & Lecturer \& Student & $\begin{array}{l}\text { Interview \& } \\
\text { Observation }\end{array}$ \\
\hline & & $\begin{array}{l}\text { The Using } \\
\text { of } \\
\text { Learning } \\
\text { Media }\end{array}$ & $\begin{array}{l}\text { Diversity of media used; } \\
\text { Media is relevant to the material; } \\
\text { Media is easily accessible; }\end{array}$ & $\begin{array}{l}\text { Lecturer } \\
\text { Lecturer \& Student } \\
\text { Lecturer \& Student }\end{array}$ & $\begin{array}{l}\text { Observation } \\
\text { Interview \& } \\
\text { Observation } \\
\text { Observation }\end{array}$ \\
\hline & & Feedback & $\begin{array}{l}\text { Feedback is given by lecturers and } \\
\text { students on each assignment or } \\
\text { exercise. }\end{array}$ & $\begin{array}{l}\text { Lecturer \& Student \& } \\
\text { Task }\end{array}$ & $\begin{array}{l}\text { Interview \& } \\
\text { Observation }\end{array}$ \\
\hline & & Evaluation & $\begin{array}{l}\text { Availability of online assessment } \\
\text { facilities. }\end{array}$ & LMS & Observation \\
\hline & & HelpdeskA & $\begin{array}{l}\text { Availability of academic and } \\
\text { administrative information } \\
\text { services; } \\
\text { Availability of online tutoring; } \\
\text { Availability of access to digital } \\
\text { library learning resources; } \\
\text { The availability of technical } \\
\text { assistance and complaints online. }\end{array}$ & $\begin{array}{l}\text { Information syster } \\
\text { Lecturer \& Student LMS } \\
\text { Digital Library }\end{array}$ & $\begin{array}{l}\text { mObservation } \\
\text { Interview \& } \\
\text { Observation } \\
\text { Observation } \\
\text { Observation }\end{array}$ \\
\hline & $\begin{array}{l}\text { Produc } \\
\mathbf{t}\end{array}$ & c Output & $\begin{array}{l}\text { The achievement of learning } \\
\text { objectives. }\end{array}$ & Lecturer \& Student & Wawancara \\
\hline & & Outcome & $\begin{array}{l}\text { Improving the quality of } \\
\text { graduation; } \\
\text { Increasing the number of students } \\
\text { to pursue tertiary education due to } \\
\text { the ease of access to learning. }\end{array}$ & $\begin{array}{l}\text { User \& Graduate Vice } \\
\text { Rector } 1 \text { \& data Student } \\
\text { Affair }\end{array}$ & $\begin{array}{l}\text { Wawancara } \\
\text { Interview \& } \\
\text { Observation }\end{array}$ \\
\hline
\end{tabular}

\section{Result and Discussion}

\subsection{Component of Context}

The component of context in e-learning program is reviewed from the analysis of the need to use e-learning in institution and the legal basis used. Based on the results obtained, there are two main needs in this program, namely first providing maximum access to education through PJJ by using full e-learning facilities. Distributed learning, which means learning that not only takes place on campus, but also in places far from campus (Macdonald, 2008). Volery \& Lord, said that distance learning is defined as learning that occurs at different places and times (Volery \& Lord, 2000). Distance learning emerged as a way to expand access for students who have limitations to attend directly because they are located far from the learning center (Perry \& Pilati, 2011). Second is e-learning as supplement or additional material given to students, where students are given the freedom to choose whether to use electronic learning material or not (Suartama: 2014). While the basis for implementing e-learning is Permendikbud Number 
109 of 2013 concerning the Implementation of Distance Education in HigherEducation.

\subsection{Component of Input}

There are 6 components of input in the evaluation of e-learning programs that have results, namely:

a) The learning design is not entirely complete and it has not been arranged in digital form, it is more detailed that where the institutions basically has a complete RPS and SAP each course that contains the identity, learning outcomes, and sequence of material, but not all have a competency map and only the Pamulang University which includes it in digital form or uploaded in LMS;

b) The implementation of e-learning is not all equipped with clear guidelines, where Unpam has e-learning procedures in the form of clear manuals, whereas other universities only provide information on how to learn online;

c) Both universities have specialized institutions that handle e-learning;

d) Human resources owned by the institutions for the development of e-learning programs are still not integrated into other units, it is clear that only Unpam has operators, technicians, and leaders of specialized institutions that handle e-learning, while other institutions for operators and technicians still join Unpam;

e) PT is more efficient using open source LMS than building its own LMS where the institutions also relies on servers independently. For network purposes, the institutions has provided Wi-Fi / hotspot facilities in the campus area, but for computers and cellular, users are directed to be able to use private property. Currently the institution is also still developing video teleconference facilities, the development of this facility is not done on a massive scale, but only a few universities are because it requires a large enough cost;

f) Learning resources in the form of e-modules or e-books and have used external links as learning resources with references that are used in accordance with the material being taught.

\subsection{Component of Process}

In the component of process, there are 7 aspects that are evaluated, showing the results, namely:

a) The learning process already refers to learning outcomes, but not yet coherently and comprehensively. All universities also do not yet have instructions on how to study clear or randomly or sequentially suitable material according to chapters or linked to certain material with presentations that are also not yet varied, and have not yet arouse the desire of students to learn, but for presentations it is possible to learninteractively;

b) Both universities have developed strategies to utilize discussion and evaluation forums, but it have not able to create a discussion topic that increases students' critical thinking, so that e-learning programs have not able to encourage the growth of new ideas in the form of critical questions, illustrations, actual issues, and problems that require settlement;

c) All universities provide opportunities to interact optimally with various parties both synchronously and asynchronously, both simply and integrated through the e-learning portal, or carried out live either through video or audio conferences;

d) The media used is less diverse, most importantly according to the material. The use of 
visual media and other media is not yet integrated but still relevant, while for the selection of instructional media it is easy to access;

e) For lecturers who provide interesting discussion topics, it is possible that feedback can occur from 2 directions, but if the topic of discussion given is not good, it tends to be given only by lecturers;

f) Evaluation of student progress is not entirely through online media contained in the elearning LMS. This is only due to the absence of routine socialization or workshops on LMS usage techniques to compiling assessments in e-learning, so that lecturers are more likely to measure the progress of students still using face-to-face facilities;

g) $\quad$ PT is still focused on providing access to digital learning resources at its own library and the availability of technical assistance and complaints is still only during working hours either face-to-face or through the helpdesk system.

\subsection{Component of Product}

The component of product of the e-learning program includes the outputs and outcomes product. In the output, researcher found the fact that e-learning programs have not able to provide learning services that encourage the achievement of learning objectives up to $100 \%$, more precisely only able to provide an increase in cognitive aspects, whereas for the affective aspects are more emphasized on the existing environmental processes. However in terms of easy access to education, e-learning programs have had an impact on increasing the number of students.

\section{Conclusion}

Based on the results of research and discussions that have been submitted previously, it can be concluded that:

a) The context evaluation results in the e- learning program found that its main needs were first to provide maximum educational access through PJJ using full e-learning facilities, and secondly e-learning as a supplement or supplementary material provided to students, and all institution in the implementation of e-learning is in accordance with Permendikbud Number 109 of 2013 concerning the Implementation of Distance Education in Higher Education;

b) The results of the input evaluation, found that the learning design is not entirely complete and has not been compiled in digital form, not yet equipped with a clear guidebook, one of the universities does not have a specific institution that handles the development of e- learning programs, HR is still incorporated in other units, the institution is more efficient to use an open source LMS than to build its own LMS, the institution still relies on servers independently, but the Wi-Fi / hotspot facility in the campus area is available with computers and cellular users using private property. Currently it still developing video teleconference facilities, learning resources are still in the form of e-modules or e-books and not many use external links as learning resources, but the references used are in accordance with the material being taught;

c) The results of the evaluation process, it was found that learning activities have referred to learning outcomes, but do not have instructions on how to learn clear material, the presentation has not varied but allows for interactive learning for students. For learning strategies and the media used are not diverse and have not been able to encourage the 
growth of new ideas;

d) The evaluation results on the product is that the e-learning program still encourages an increase in cognitive aspects, but can increase the number of students due to the ease of access to education.

Based on the conclusions above, the authors recommend the two universities, namely:

a) For the context of the e-learning program it can be maintained, with further improvement in the aim of increasing ease of access to education;

b) For e-learning program input, there needs to be an improvement in aspects of learning design and procedures, and special institutions need to be formed in handling this program so that the completeness of its HR can be compiled. As for infrastructure, cooperation between the institutions is needed in its use so that budget efficiency can occur. As for variations in learning resources, workshops and funding assistance for lecturers for the development of digital learning resources need to be held;

c) For the input process of the e-learning program some aspects need to be maintained, but an increase in the aspects of learning activities is needed by forming a special team that is trained to develop the learning process, compiling instructions on how to study clear material, variations in presentation, not just in visual form. There is also a need for training for lecturers to be able to feed guiding questions, initiations, or case studies in order to trigger students to learn higher order thinking, create learning media, and arrange discussion topics that are case studies or dissociation learning so that feedback can occur from two directions. Managers need to provide online assessment plugins, built digital networks between universities so they can exchange learning resources;

d) For products that can provide easy access to education to the community need to be maintained, but for the suitability of the objectives it is necessary to identify problems both from the input and related processes not yet achieved the learning objectives, and PT must at least continue to provide face-to-face meetings to students to provide human touch so that all educational values remain embedded or in the form of blended learning.

\section{References}

[1] Allen, I. E., \& Seaman, J.: Learning on Demand Online Education in the United States, 2009. Distributed by ERIC Clearinghouse (2010)

[2] Arbaugh, J. B., \& Benbunan-Fich, R: An Investigation of Epistemological and Social Dimensions of Teaching in Online Learning Environments. Academy of Management Learning \& Education, 5(4), 435-447 (2006) https://doi.org/10.2307/40214402

[3] Baragash, R. S., \& Al-Samarraie, H.: Blended learning: Investigating the influence of engagement in multiple learning delivery modes on students' performance. Telematics and Informatics, 35(7), 2082-2098 (2018). https://doi.org/10.1016/j.tele.2018.07.010

[4] Barkley, E. F: Student engagement techniques: a handbook for college faculty. Jossey-Bass (2010)

[5] Bhuasiri, W., Xaymoungkhoun, O., Zo, H., Rho, J. J., \& Ciganek, A. P.: Critical success factors for e-learning in developing countries: A comparative analysis between ICT experts and faculty. $\begin{array}{lllll}\text { Computers \& } \quad \text { Education, } & \text { 58(2), }\end{array}$ https://doi.org/10.1016/J.COMPEDU.2011.10.010

[6] Bonwell, C. C., \& Eison, James, A.: Active Learning: Creating Excitement in the Classroom. 
1991 ASHE-ERIC Higher Education Reports. ASHE-ERIC Higher Education Report (1991) https://doi.org/ED340272

[7] Carliner, S.: An Overview of Online Learning (Second). Massachusetts: HRD Press(2004)

[8] Chen, P.-S. D. S. D., Lambert, A. D., \& Guidry, K. R.: Engaging online learners: The impact of Web-based learning technology on college student engagement. Computers and Education, 54(4), 1222-1232 (2010). https://doi.org/10.1016/j.compedu.2009.11.008

[9] Clark, R. Colvin.: Six Principles of Effective e-Learning: What Works and Why. The ELearning Developers Journal, 1-9 (2002)

[10] Clark, Ruth C., \& Mayer, R. E.: E-learning and The Science of Instruction: Proven Guidelines for Consumers and Designer of Multimedia Learning. Pfeiffer (Third Edit). Pfeiffer (2011). https://doi.org/10.1002/9781118255971.

[11] CNN Indonesia.: BKPM Sebut Tangerang Selatan Calon Kuat KEK Pendidikan (2019). Diakses pada tanggal 24 Mei 2019. https://www.cnnindonesia.com/ekonomi/20190311125441-532376162/bkpm-sebut-tangerang-selatan-calon-kuat-kek-pendidikan.

[12] Crawford-Ferre, Heather GlynnWiest, Lynda R.:Effective Online Instruction in Higher Education. Quarterly Review of Distance Education, 13(1), 11-14 (2012)

[13] Creswell, W. J.: Research Design: Pendekatan Metode Kualitatif, Kuantitatif, dan campuran. Yogyakarta: Pustaka Pelajar (2006)

[14] Davis, D., Chen, G., Hauff, C., \& Houben, G.-J. J.: Activating learning at scale: A review of innovations in online learning strategies. Computers and Education, 125(May), 327-344 (2018) https://doi.org/10.1016/j.compedu.2018.05.019

[15] Dixson, M. D.: Measuring student engagement in the online course: the Online Student Engagement scale (OSE).(Section II: Faculty Attitudes and Student Engagement)(Report). Online Learning Journal (OLJ), 19(4), 143 (2015). https://doi.org/10.24059/olj.v19i4.561.

[16] Wand, Edwin, and Brown, Gerald W.: Essentials of Educational Evaluation. New York: Holt Rinehart and Winston (1957)

[17] Fredricks, J. A., Blumenfeld, P. C., \& Paris, A. H.: School Engagement: Potential of the Concept, State of the Evidence. Review of Educational Research, 74(1), 59-109 (2004) https://doi.org/10.3102/00346543074001059

[18] George D. Kuh, Ty M. Cruce, Rick Shoup, Jillian Kinzie, Robert M. Gonyea, Kuh, G. D., ... Gonyea, R. M.: Unmasking the Effects of Student Engagement on First-Year College Grades and Persistence. The Journal of Higher Education, 79(5), 540-563 (2008) https://doi.org/10.1353/jhe.0.0019

[19] Goodyear Salmon, G., Spector, M., Steeples, C. i Tickner, S., P.: Competences for online teaching. Educational Technology Research \& Development, 49, 65-72(2001)

Henrie, C. R., Halverson, L. R., \& Graham, C. R.: Measuring student engagement in technologymediated learning: A review. Computers \& Education, 90, 36-53 (2015) https://doi.org/10.1016/J.COMPEDU.2015.09.005

[20] Jacobson, D., Chapman, R., Ye, C., \& Van Os, J.: A Project-Based Approach to Executive Education. Decision Sciences Journal of Innovative Education, 15(1), 42-61 (2017) https://doi.org/10.1111/dsji.12116.

[21] Jauch Lawrence R. \& Glueck William F.: Manajemen Dan Strategis Kebijakan Perusahaan. Jakarta: Erlangga (1999)

[22] Jones, Charles.: Pengantar Kebijakan Publik. Jakarta: PT. Raja Grafindo (1994)

[23] Kauffman, Roger \& Thomas, Susan.: Evaluation Without Fear. New York: New View Points (1980)

[24] Kraiger, K., Ford, J. K., \& Salas, E.: Application of Cognitive, Skill-Based, and Affective Theories of Learning Outcomes to New Methods of Training Evaluation. Journal of Applied Psychology, 78(2), 311-328 (1993) https://doi.org/10.1037/0021-9010.78.2.311

[25] Lapsley, R., Kulik, B., Moody, R., \& Arbaugh, B.: Is Identical Really Identical? An Investigation of Equivalency Theory and Online Learning. The Journal of Educators Online, 5(1), 1-19(2008)

[26] Lee, J. S.: The relationship between student engagement and academic performance: Is it a myth 
or reality? Journal of Educational Research, 107(3), 177-185 https://doi.org/10.1080/00220671.2013.807491

[27] Lyke, J., \& Frank, M.: Comparison of student learning outcomes in online and traditional classroom environments in a psychology course. Journal of Instructional Psychology, 39(3), 245-250 (2012)

[28] Macdonald, J.: Blended Learning and Online Tutoring: Planning Learner Support and Activity $\begin{array}{lllll}\text { Design. Gower Publishing Limiterd (Second Edi, Vol. 30) (2008) } & \end{array}$ https://doi.org/10.1038/embor.2010.103

[29] Markova, T., Glazkova, I., \& Zaborova, E.: Quality Issues of Online Distance Learning. Procedia $\begin{array}{lllll}\text { Social and Behavioral Sciences, 237(June 2016), 685-691 (2017) } & \end{array}$ https://doi.org/10.1016/j.sbspro.2017.02.043

[30] Mashaw, B.: A Model for Measuring Effectiveness of an Online Course. Decision Sciences Journal of Innovative Education, 10(2), 189-221 (2012) https://doi.org/10.1111/j.15404609.2011.00340.x.

[31] Mulyatiningsih, Endang.: Metode Penelitian Terapan Bidang Pendidikan. Bandung: Alfabeta (2011)

[32] Nichols, M.: A theory for eLearning. Educational Technology \& Society, 6(2), 1-10 (2003)

[33] Ozkan, S., \& Koseler, R.: Multi-dimensional students' evaluation of e-learning systems in the higher education context: An empirical investigation. Computers \& Education, 53(4), 1285-1296 (2009) https://doi.org/10.1016/J.COMPEDU.2009.06.011

[34] Pascarella, E. T., Seifert, T. A., \& Whitt, E. J.: Effective instruction and college student persistence: Some new evidence. New Directions for Teaching and Learning, 2008(115), 55-70 (2008) https://doi.org/10.1002/t1.325

[35] Perry, E. H., \& Pilati, M. L.: Online learning. New Directions for Teaching and Learning, 2011(128), 95-104 (2011) https://doi.org/10.1002/tl.472

[36] Randolph, K. A., Fraser, M. W., \& Orthner, D. K.: Educational resilience among youth at risk. Substance Use and Misuse, 39(5), 747-767+844 (2004) https://doi.org/10.1081/JA-120034014

[37] Shukor, N. A., Tasir, Z., Van der Meijden, H., \& Harun, J.: A Predictive Model to Evaluate Students' Cognitive Engagement in Online Learning. Procedia - Social and Behavioral Sciences, 116(2006), 4844-4853 (2014) https://doi.org/10.1016/j.sbspro.2014.01.1036

[38] Sitzmann, T., Kraiger, K., Stewart, D., \& Wisher, R.: The comparative effectiveness of web-based and classroom instruction: A meta-analysis. Personnel Psychology, 59(3), 623-664 (2014) https://doi.org/10.1111/j.1744-6570.2006.00049.x

[39] Suartama, Kadek, I \& Tastra, Kadek, I.D.: E-learninf Berbasis Moodle. Yogyakarta: Graha Ilmu (2014)

[40] Sun, P.-C. C., Tsai, R. J., Finger, G., Chen, Y.-Y. Y., \& Yeh, D.: What drives a successful eLearning? An empirical investigation of the critical factors influencing learner satisfaction. $\begin{array}{lllll}\text { Computers and } & \text { Education, } & \text { 50(4), } & 1183-1202 & \text { (2008) }\end{array}$ https://doi.org/10.1016/j.compedu.2006.11.007

[41] Volery, T., \& Lord, D.: Critical success factors in online education. International Journal of Educational Management, 14(5), 216-223 (2000) https://doi.org/10.1108/09513540010344731

[42] Wang, F. H.: An exploration of online behaviour engagement and achievement in flipped classroom supported by learning management system. Computers and Education, 114, 79-91 (2017) https://doi.org/10.1016/j.compedu.2017.06.012

[43] Weber, J. M., \& Lennon, R.: Multi-Course Comparison of Traditional versus Web-based Course Delivery Systems. The Journal of Educators Online (Vol. 4)(2007)

[44] Worthen, B.R \& Sanders, J.R.: Educational Evaluation. Alternative Approaches and Practical Guidelines. New York \& London: Longman Inc (1987)

[45] Wuebker, M. P.: Adult Learners: Improving Persistence and Performance in Online Learning Environments. Journal of College Literacy and Learning, 39, 38-46(2013) 